dr hab. inż. Marian Medwid prof. nadzw.

mgr inz. Krzysztof Lukaszewski

mgr inz. Karol Bryk

Instytut Pojazdów Szynowych „,TABOR”

\title{
Analiza bezpieczeństwa jazdy modułowego pojazdu do transportu kombinowanego, kolejowo-drogowego w oparciu o symulację komputerową
}

\begin{abstract}
Niniejszy artykut zawiera wyniki analizy bezpieczeństwa jazdy nowej konstrukcji pojazdu do transportu kombinowanego, kolejowo-drogowego w oparciu o symulacje komputerowa. Bezpieczeństwo jazdy rozumiane jest jako wptywy wzdlużnych sit ściskajacych powstajacych podczas przyjazdu przez tory wichrowate jak również podczas przepychania pojazdu na tuku S. Przeprowadzone badania oparte sq o wymagania zawarte w karcie UIC 530-2.

Scenariusze badań oraz wyniki odnoszace się do pojazdu modułowego do transportu kolejowo-drogowego, prezentowane $w$ artykule, sq wynikiem prac badawczych przeprowadzonych $w$ ramach realizacji projektu rozwojowego $\mathrm{nr}$ R10-0065-10 „System transportu naczep drogowych na wózkach kolejowych $w$ kombinowanym ruchu kolejowo-drogowym".
\end{abstract}

\section{PREZENTACJA BADANEGO MODELU}

Badania symulacyjne zostały przeprowadzone dla trzech wariantów składu pociągów określonych na podstawie wytycznych zawartych $\mathrm{w}$ karcie [1]. Zasadniczą częścią każdego z omawianych wariantów pociagu jest badany zestaw pojazdów do transportu kombinowanego składający się z dwóch kompletnych platform (dwóch modułów jednego wagonu), schematycznie przedstawionych na rysunku 1.1. Pierwsza platforma (moduł 1) jest obrócony o $180^{\circ} \mathrm{w}$ porównaniu do platformy drugiej (moduł 2).

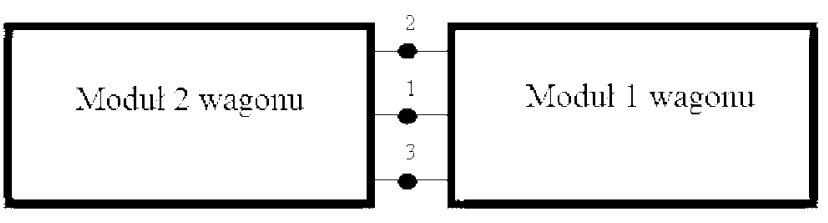

Rys. 1.1 - Schemat połączeń pomiędzy modułami wagonu: 1- element modelujący sprzęg (dwa szeregowo połączone amortyzatory sprzęgu), 2,3 - element modelujący zderzak

Współczynnik tarcia przyjęty dla tarcz zderzaków wynosi $\mu=0,1$

$\mathrm{Z}$ racji specyficznej konstrukcji omawianych 
platform do transportu kombinowanego konieczne jest sprzęgnięcie dwóch takich pojazdów (tak jak przedstawiony na rys. 1), w innym przypadku nie było by możliwe skonfigurowanie pociagu w skład którego wchodzą inne wagony. Pociąg składający się tylko z wagonów omawianego typu wymaga również tworzenia wspomnianych par modułów.

Ogólny schemat składu pociąu wykorzystywanego w badaniach bezpieczeństwa jazdy wraz z opisami przedstawiono na rys. 1.2. Rysunek 1.2 jest zgodny z rysunkiem 1.1 na którym przez moduł 1 i 2 oznaczono wagonu do transportu kombinowanego.

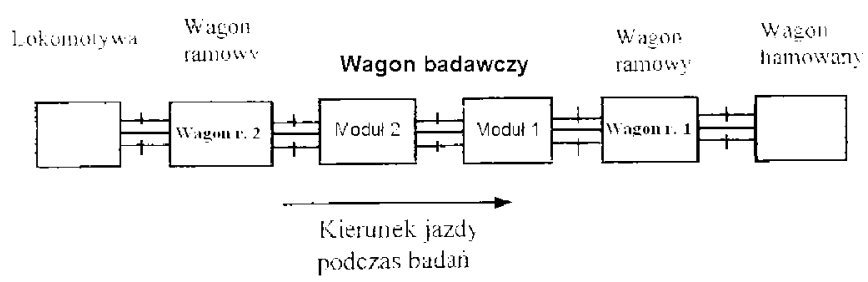

Rys. 1.2 - Schemat pociagu wykorzystywanego w badaniach bezpieczeństwa jazdy opracowany na podstawi karty UIC 530-2

Analogicznie do opisanego powyżej modelu mechanicznego w programie SIMPACK 9.3.1 opracowano model w którego skład wchodzą dwa modułu wagonu badawczego przedstawione na rysunku 1.3.

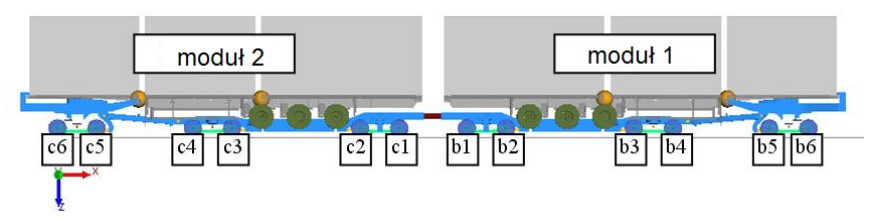

Rys. 1.3 - Widok modelu składu pojazdów do transportu kombinowanego (dwa wagony badane) wraz z oznaczeniami wagonów i zestawów kołowych w programie SIMPACK

Na podstawie wytycznych zawartych w karcie UIC 530-2 zbudowano trzy warianty pociagów wykorzystanych w badaniach omawianego pojazdu i przedstawiono je na rysunkach 1.4, 1.5 i 1.6 .

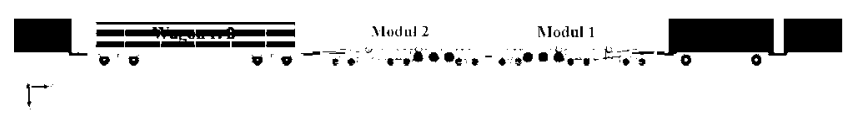

Rys. 1.4 - Konfiguracja standardowa pociagu badawczego, gdzie: $\mathrm{H}$ - wagon hamowany, A - lokomotywa, W. r. 1 - dwuosiowy wagon towarowy (Fcs), W. r. 2 - platforma towarowa (Rs)

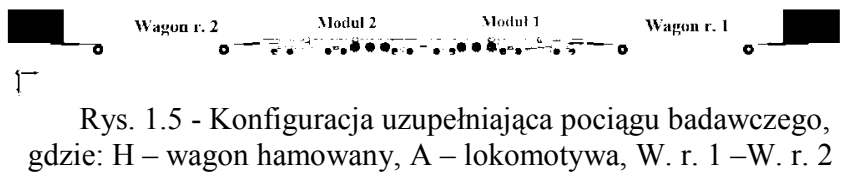
gdzie: H - wagon hamowany, A - lokomotywa, W. r. 1 -W r r. 2 - długi dwuosiowy wagon towarowy

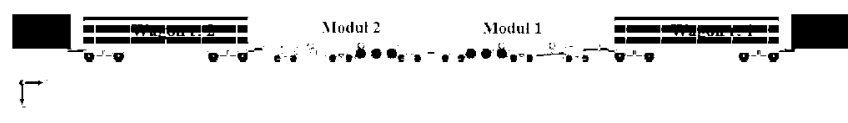

Rys. 1.6 - Konfiguracja uzupełniająca pociągu badawczego, gdzie: H - wagon hamowany, A - lokomotywa, W. r. 1 -W. r. 2 - platforma towarowa

\section{TOR BADAWCZY}

Zgodnie $\mathrm{z}$ wytycznymi zawartymi $\mathrm{w}$ karcie UIC 530-2 i normie PN-EN-14363 zbudowano w programie SIMPACK tor doświadczalny w kształcie litery $\mathrm{S}$ o promieniu $\mathrm{R}=150 \mathrm{~m}$, posiadającym odcinek prosty toru wynoszący $6 \mathrm{~m}$, tak jak na rysunku 2.1 .

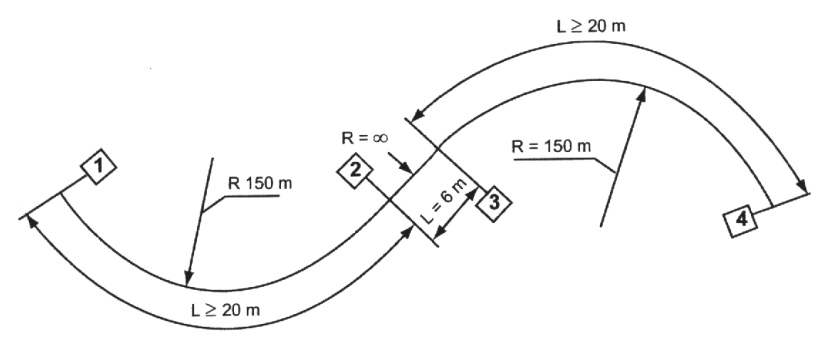

Rys. 2.1 - Tor doświadczalny w kształcie litery S [1]

Tor badawczy nie posiada przechyłek a jego średni prześwit wynosi od 1450 do $1465 \mathrm{~mm}$.

W przeprowadzonych badaniach symulacyjnych przyjęto długość łuku wynoszącą $\mathrm{L}=25 \mathrm{~m}$ oraz zastosowano tor o prześwicie $1460 \mathrm{~mm}$ na całym odcinku badawczym.

Karta UIC 530-2 zawiera również opis toru doświadczalnego składającego się z pełnego łuku o promieniu $\mathrm{R}=150 \mathrm{~m}$ i długości wynoszącej co najmniej $50 \mathrm{~m}$. W przypadku przeprowadzenia badań na torze $\mathrm{w}$ kształcie litery $\mathrm{S}$ nie jest wymagane przeprowadzenie badań na omawianym łuku o promieniu $\mathrm{R}$ $=150 \mathrm{~m}$.

\section{KRYTERIA OCENY}

Do oceny wyników badań przyjęto kryteria zawarte w karcie UIC 530-2:

Przenoszona siła wzdłużna jest osiagnięta wtedy, gdy jest przekroczona jedna z następujących wartości granicznych:

- uniesienie koła nieprowadzącego $\mathrm{d}_{\mathrm{zj}} \leq 50 \mathrm{~mm}$ na odcinku ? $2 \mathrm{~m}$;

- wspinanie prowadzących kół $\mathrm{d}_{\mathrm{zj}} \geq 5 \mathrm{~mm}$ przy pionowych naciskach kół $\mathrm{Q}_{\mathrm{ij}}<0$; koła prowadzące są kołami 11 i 12 dla wagonów towarowych dwuosiowych (kryterium należy sprawdzać tylko dla pociagów próbnych w konfiguracji uzupełniającej);

- obciążenie przymocowanego toru $\mathrm{H}_{\lim }(2 \mathrm{~m}) \geq$ $25+0,6 \times 2 \times Q_{0}(\mathrm{kN})$

- $\mathrm{Q}_{\mathrm{o}}$ - średni statyczny pionowy nacisk koła na szynę;

- poziome minimalne pokrycie tarcz zderzakowych $\mathrm{d}_{\mathrm{yp} 1} \mathrm{id}_{\mathrm{yp} 2} \leq 25 \mathrm{~mm}$.

Dla każdej próby należy wyznaczyć:

- $\mathrm{H}_{\mathrm{yi}}$ i $\mathrm{d}_{\mathrm{zij}}$ jako wartość mierzoną na odcinku toru o długości $2 \mathrm{~m}$; 
- $\mathrm{d}_{\mathrm{zij}}$ jako wspinanie się kół prowadzących (ocenę należy sprawdzić tylko w pociagach badawczych w konfiguracji uzupełniającej);

- $\mathrm{F}_{\mathrm{Lx}}$ - wzdłużna siła ściskająca;

- $\mathrm{d}_{\mathrm{ypi}}-$ pokrycie tarczy zderzaków.

Dla wagonów towarowych wózkowych wyposażonych w sprzęgi śrubowe i zderzaki boczne, należy udokumentować możliwość przeniesienia wzdłużnej siły ściskającej na poziomie $240 \mathrm{kN}$, poprzez próby pchania na łuku w kształcie litery S. Minimalna wzdłużna siła ściskająca wynosząca 240 $\mathrm{kN}$ dla wagonów towarowych $\mathrm{z}$ wózkami dwuosiowymi powinna być przekroczona o około 10\% [1].

Badania symulacyjne pojazdu do transportu kolejowo-drogowego zostały przeprowadzone na łuku w kształcie litery $\mathrm{S}$ z prędkością $8 \mathrm{~km} / \mathrm{h}$.

\section{UZYSKANE WYNIKI DLA KONSTRUKCJI WYJŚCIOWEJ}

Konstrukcję wyjściową przedstawiono na rysunku 5.1

Wybrane maksymalne wartości uzyskanych wyników dla konfiguracji standardowej z siłą ściskająca która wynosi $198 \mathbf{~ k N}$ przedstawiono $\mathrm{w}$ tabeli 4.1, 4.2 i 4.3.

Tabela 4.1 - Maksymalne uzyskane wartości wspinania i unoszenia się kól analizowanego pojazdu w konfiguracji standardowej - sila ściskająca $198 \mathrm{kN}$

\begin{tabular}{|c|c|c|c|c|c|c|c|}
\hline \multirow[b]{2}{*}{ L.p. } & \multirow{2}{*}{$\begin{array}{l}\text { Zestaw } \\
\text { kolowy }\end{array}$} & \multicolumn{3}{|c|}{ Wspinanie $d_{z}[\mathrm{~mm}]$} & \multicolumn{3}{|c|}{ Unoszenie $d_{z}[\mathrm{~mm}]$} \\
\hline & & $\mathbf{d z}_{\text {lim }}$ & Kolo lewe & $\begin{array}{l}\text { Kolo pra- } \\
\text { we }\end{array}$ & $\mathrm{dz}_{\text {lim }}$ & $\begin{array}{l}\text { Kolo } \\
\text { lewe }\end{array}$ & $\begin{array}{l}\text { Kolo } \\
\text { prawe }\end{array}$ \\
\hline 1 & b6 & \multirow{12}{*}{5,0} & 0,9 & 1,7 & \multirow{12}{*}{50,0} & 7,7 & 1,5 \\
\hline 2 & b5 & & 1,0 & 1,6 & & 8,8 & 0,5 \\
\hline 3 & b4 & & 1,0 & 1,0 & & - & - \\
\hline 4 & b3 & & 0,5 & 0,4 & & - & - \\
\hline 5 & $\mathrm{~b} 2$ & & 1,1 & 1,1 & & - & - \\
\hline 6 & b1 & & 1,1 & 1,0 & & - & - \\
\hline 7 & $\mathrm{cl}$ & & 0,35 & 0,89 & & - & - \\
\hline 8 & c2 & & 1,0 & 1,1 & & - & - \\
\hline 9 & $\mathrm{c} 3$ & & 0,4 & 0,4 & & - & - \\
\hline 10 & $\mathrm{c} 4$ & & 0,9 & 1,0 & & - & - \\
\hline 11 & $\mathrm{c} 5$ & & 1,1 & 1,1 & & - & - \\
\hline 12 & c6 & & 1,1 & 1,1 & & - & - \\
\hline
\end{tabular}

Tabela 4.2 - Maksymalne uzyskane wartości poprzecznej siły lożyskowej na zestawie kołowym - siła ściskająca 198 kN

\begin{tabular}{|c|c|c|c|c|}
\hline L.p. & $\begin{array}{c}\text { Zestaw } \\
\text { kolowy }\end{array}$ & $\begin{array}{c}\mathbf{Q}_{\mathbf{0}} \\
{[\mathbf{k N}]}\end{array}$ & $\begin{array}{c}\mathbf{H}_{\text {lim }} \\
{[\mathbf{k N}]}\end{array}$ & $\mathbf{H}[\mathbf{k N ]}]$ \\
\hline 1 & $\mathrm{~b} 6$ & 20,0 & \pm 49 & $-12,1$ \\
\hline 2 & $\mathrm{~b} 5$ & 20,0 & \pm 49 & 17,9 \\
\hline 3 & $\mathrm{~b} 4$ & 16,6 & \pm 45 & 10,0 \\
\hline 4 & $\mathrm{~b} 3$ & 16,6 & \pm 45 & $-14,1$ \\
\hline 5 & $\mathrm{~b} 2$ & 19,1 & \pm 48 & $-15,5$ \\
\hline 6 & $\mathrm{~b} 1$ & 19,1 & \pm 48 & $-32,0$ \\
\hline 7 & $\mathrm{c} 1$ & 19,1 & \pm 48 & 20,0 \\
\hline 8 & $\mathrm{c} 2$ & 19,1 & \pm 48 & 17,0 \\
\hline 9 & $\mathrm{c} 3$ & 16,6 & \pm 45 & 11,0 \\
\hline 10 & $\mathrm{c} 4$ & 16,6 & \pm 45 & $-12,7$ \\
\hline 11 & $\mathrm{c} 5$ & 20,0 & \pm 49 & 15,1 \\
\hline 12 & $\mathrm{c} 6$ & 20,0 & \pm 49 & $-37,4$ \\
\hline
\end{tabular}

Tabela 4.3 - Maksymalne uzyskane wartości przemieszczenia poprzecznego pomiędzy zderzakami - siła ściskająca 198 kN

\begin{tabular}{|c|c|}
\hline Zderzaki & $\begin{array}{r}\text { Przemieszczenie poprzeczne } \\
\text { zderzaków } \mathbf{d}_{\mathbf{v p}}[\mathbf{m m}]\end{array}$ \\
\hline przednie & 7,5 \\
\hline tylne & 190,0 \\
\hline
\end{tabular}

Wybrane maksymalne wartości uzyskanych wyników dla konfiguracji standardowej z siłą ściskająca która wynosi $231 \mathbf{~ k N}$ przedstawiono $\mathrm{w}$ tabeli $4.4,4.5$ i 4.6 oraz na rysunkach 4.1 .

Tabela 4.4 - Maksymalne uzyskane wartości wspinania i unoszenia się kól analizowanego pojazdu w konfiguracji standardowej - sila ściskająca $231 \mathrm{kN}$

\begin{tabular}{|c|c|c|c|c|c|c|c|}
\hline \multirow[b]{2}{*}{ L.p. } & \multirow{2}{*}{$\begin{array}{l}\text { Zestaw } \\
\text { kolowy }\end{array}$} & \multicolumn{3}{|c|}{ Wspinanie $d_{z}[\mathrm{~mm}]$} & \multicolumn{3}{|c|}{ Unoszenie $d_{z}[\mathrm{~mm}]$} \\
\hline & & $\mathbf{d z} z_{\text {lim }}$ & $\begin{array}{l}\text { Koło } \\
\text { lewe }\end{array}$ & $\begin{array}{l}\text { Koło } \\
\text { prawe }\end{array}$ & $\mathbf{d z}_{\mathrm{lim}}$ & $\begin{array}{l}\text { Kolo } \\
\text { lewe }\end{array}$ & $\begin{array}{c}\text { Kolo } \\
\text { prawe }\end{array}$ \\
\hline 1 & $\mathrm{~b} 6$ & \multirow{12}{*}{5,0} & 3,0 & 9,0 & \multirow{12}{*}{50,0} & 31 & 13,2 \\
\hline 2 & b5 & & 1,0 & 4,5 & & 35 & 15 \\
\hline 3 & b4 & & 1,1 & 1,0 & & - & - \\
\hline 4 & b3 & & 0,5 & 0,5 & & - & - \\
\hline 5 & b2 & & 1,1 & 1,1 & & - & - \\
\hline 6 & $\mathrm{~b} 1$ & & 1,1 & 1,0 & & - & - \\
\hline 7 & $\mathrm{c} 1$ & & 1,1 & 1,0 & & - & - \\
\hline 8 & $\mathrm{c} 2$ & & 0,5 & 0,8 & & - & - \\
\hline 9 & c3 & & 1,0 & 1,0 & & - & - \\
\hline 10 & $\mathrm{c} 4$ & & 0,4 & 0,4 & & - & - \\
\hline 11 & $\mathrm{c5}$ & & 1,1 & 1,0 & & - & - \\
\hline 12 & $\mathrm{c} 6$ & & 1,1 & 1,1 & & - & - \\
\hline
\end{tabular}

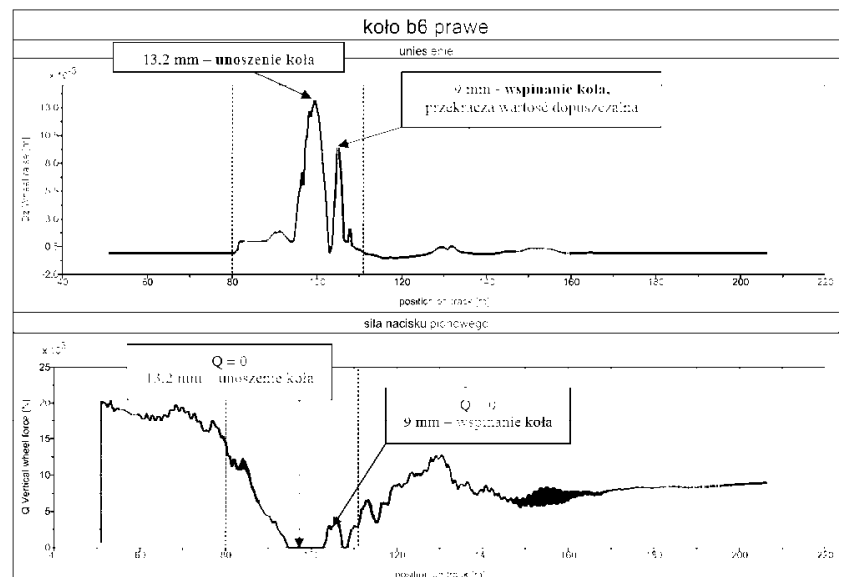

Rys. 4.1 - Pionowe unoszenie koła względem główki szyny siła ściskająca $231 \mathrm{kN}$

\begin{tabular}{|c|c|c|c|c|}
\hline L.p. & $\begin{array}{c}\text { Zestaw } \\
\text { kołowy }\end{array}$ & $\begin{array}{c}\mathbf{Q}_{\mathbf{0}} \\
{[\mathbf{k N}]}\end{array}$ & $\begin{array}{c}\mathbf{H}_{\mathbf{l i m}} \\
{[\mathbf{k N}]}\end{array}$ & $\begin{array}{c}\mathbf{H} \\
{[\mathbf{k N}]}\end{array}$ \\
\hline 1 & $\mathrm{~b} 6$ & 20,0 & \pm 49 & 12,0 \\
\hline 2 & $\mathrm{~b} 5$ & 20,0 & \pm 49 & 17,0 \\
\hline 3 & $\mathrm{~b} 4$ & 16,6 & \pm 45 & 10,0 \\
\hline 4 & $\mathrm{~b} 3$ & 16,6 & \pm 45 & 12,0 \\
\hline 5 & $\mathrm{~b} 2$ & 19,1 & \pm 48 & $-16,0$ \\
\hline 6 & $\mathrm{~b} 1$ & 19,1 & \pm 48 & $-34,0$ \\
\hline 7 & $\mathrm{c} 1$ & 19,1 & \pm 48 & 22,0 \\
\hline 8 & $\mathrm{c} 2$ & 19,1 & \pm 48 & 20,0 \\
\hline 9 & $\mathrm{c} 3$ & 16,6 & \pm 45 & 10,0 \\
\hline 10 & $\mathrm{c} 4$ & 16,6 & \pm 45 & $-13,0$ \\
\hline 11 & $\mathrm{c} 5$ & 20,0 & \pm 49 & $-20,0$ \\
\hline 12 & $\mathrm{c} 6$ & 20,0 & \pm 49 & $-39,0$ \\
\hline
\end{tabular}

Tabela 4.5 Maksymalne uzyskane wartości poprzecznej siły łożyskowej na zestawie kołowym - siła ściskająca $231 \mathrm{kN}$ 
Tabela 4.6 - Maksymalne uzyskane wartości przemieszczenia poprzecznego pomiędzy zderzakami - siła ściskająca 231 kN

\begin{tabular}{|c|c|}
\hline Zderzaki & $\begin{array}{c}\text { Przemieszczenie poprzeczne } \\
\text { zderzaków } \mathbf{d}_{\mathbf{v p}}[\mathbf{m m}]\end{array}$ \\
\hline przednie & 6,4 \\
\hline tylne & 180,0 \\
\hline
\end{tabular}

Przedstawione powyżej wyniki odnoszące się do początkowych założeń konstrukcyjnych które nie spełniają przyjętych wymagań odnośnie przenoszenia wzdłużnej siły ściskającej. Uzyskana maksymalna wartość siły ściskającej dla przejazdu przez tor w kształcie litery S w kombinacji standardowej wynosi $198 \mathrm{kN}$ i jest niższa od wymaganej dla wagonów towarowych wózkowych minimalnej siły ściskającej, która wynosi $264(240+10 \%) \mathrm{kN}$. W przypadku kombinacji uzupełniających uzyskane wartości ocenianych parametrów nie przekroczyły wartości krytycznych. Przenoszenie sił wyższych niż 198 kN powoduje nadmierne wspinanie się koła na główkę szyny a więc zgodnie z [1] taki przejazd należy uznać za niebezpieczny. Omawianą negatywną tendencję ilustruje rysunek 4.1 na którym przedstawiono zachowanie się koła względem szyn pod wpływem wzdłużnej siły ściskającej która wynosi 231 kN. Widoczne jest nadmierne wspinanie się kola na wysokość $9 \mathrm{~mm}$, które znacznie przekracza wartość graniczną która wynosi $5 \mathrm{~mm}$.

\section{UZYSKANE WYNIKI DLA KONSTRUKCJI ALTERNATYWNEJ}

$Z$ racji nie spełnienia przez analizowany model pojazdu wytycznych zawartych w karcie UIC 530-2 przeprowadzono dodatkowe badania mające na celu zapewnienia możliwości przenoszenia minimalnej wzdłużnej siły ściskającej która wynosi $264 \mathrm{kN}$ $(240 \mathrm{kN}+10 \%)$.
Elementem który został poddany modyfikacji przedstawiono schematycznie na rysunku 5.1: element łączący 2 platformę pod koła naczepy drogowej $1 \mathrm{z}$ ramą pod siodło naczepy 3. Po wprowadzeniu zmian element łączący znajduje się w położeniu poziomym co zapobiega odciążaniu wózka znajdującego się pod siodłem naczepy drogowej podczas przenoszenia wzdłużnej siły ściskającej. Przegub łączący 4 po modyfikacji jest o $7 \mathrm{~cm}$ wyżej od swojego położenia pierwotnego a sworznie 5 zostały opuszczone o $12 \mathrm{~cm}$. Z przeprowadzonych badań wynika że przegub 4 podczas przejazdu przez tor badawczy przenosi duże siły poprzeczne które w znaczący sposób zwiększają wzdłużny moment skręcający w naczepie co za tym idzie tendencję wózka znajdującego się pod gniazdem naczepy do unoszenia jego kół. Alternatywne położenie rozpatrywanego węzła zmniejsza opisane wyżej niekorzystne tendencje.

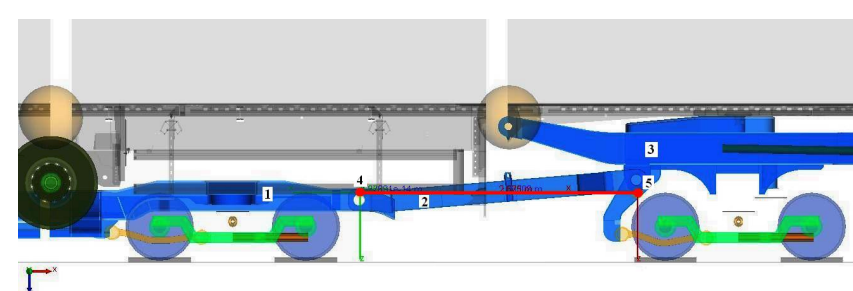

Rys. 5.1 - Miejsce poddane modyfikacji, zmiana położenia elementu łączącego oznaczona czerwoną linią: 1 - platforma pod koła naczepy drogowej; 2 - element łączący; 3 - rama pod gniazdo naczepy drogowej; 4 - przegub; 5 - sworznie

W celu dalszej poprawy zastosowano naczepę o zwiększonej poprzecznej sztywności skrętnej o około $50 \%$ co daje odpowiednio dla elementu $18 \mathrm{c}_{\alpha}=$

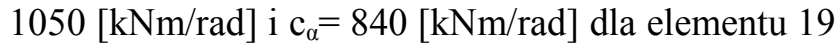
(rys. 5.2), omawiany wariant naczepy był również realizowany w pracach konstrukcyjnych.

Wyniki uzyskane podczas przejazdu konfiguracji standardowej pociagu badawczego z siłą ściskająca wynosząca $264(240+10 \%) \mathrm{kN}$ przedstawiono w tabelach 5.1, 5.2 i 5.3 oraz na rysunkach 5.3, 5.4 i 5.5 .

Tabela 5.1 - Maksymalne uzyskane wartości wspinania i unoszenia się kół analizowanego pojazdu po modyfikacji w konfiguracji standardowej - sila ściskająca $264(240+10 \%)$ kN

\begin{tabular}{|c|c|c|c|c|c|c|c|}
\hline \multirow[b]{2}{*}{ L.p. } & \multirow{2}{*}{$\begin{array}{l}\text { Zestaw } \\
\text { kolowy }\end{array}$} & \multicolumn{3}{|c|}{ Wspinanie $d_{z}[\mathrm{~mm}]$} & \multicolumn{3}{|c|}{ Unoszenie $d_{z}[\mathrm{~mm}]$} \\
\hline & & $\mathbf{d z} \mathbf{z}_{\lim }$ & Koło lewe & Kolo prawe & $\mathbf{d z} z_{\lim }$ & Koło lewe & $\begin{array}{c}\text { Kolo } \\
\text { prawe }\end{array}$ \\
\hline 1 & b6 & \multirow{12}{*}{5,0} & 1,7 & 2,0 & \multirow{12}{*}{50,0} & - & - \\
\hline 2 & b5 & & 0,8 & 1,0 & & 5,0 & - \\
\hline 3 & b4 & & 1,1 & 1,1 & & - & - \\
\hline 4 & b3 & & 0,5 & 0,4 & & - & - \\
\hline 5 & $\mathrm{~b} 2$ & & 1,1 & 1,1 & & - & - \\
\hline 6 & b1 & & 1,1 & 1,0 & & - & - \\
\hline 7 & $\mathrm{c} 1$ & & 1,1 & 1,1 & & - & - \\
\hline 8 & $\mathrm{c} 2$ & & 0,8 & 0,5 & & - & - \\
\hline 9 & c3 & & 1,0 & 1,0 & & - & - \\
\hline 10 & $\mathrm{c} 4$ & & 0,4 & 0,4 & & - & - \\
\hline 11 & $\mathrm{c} 5$ & & 1,1 & 1,1 & & - & - \\
\hline 12 & c6 & & 1,1 & 1,1 & & - & - \\
\hline
\end{tabular}




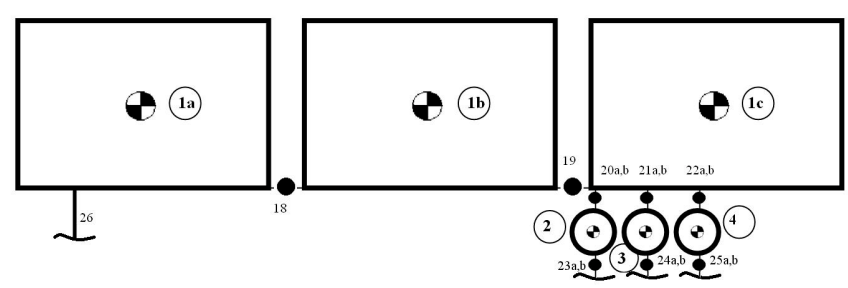

Rys. 5.2 - Model mechaniczny naczepy: 1a, 1b, 1c, 2, 3, 4bryły sztywne naczepy; 18, 19, 20ab, 21ab, 22ab, 23ab, 24ab, $25 \mathrm{ab}$ - elementy podatne naczepy; 26 - element realizujący połączenie naczepy z platformą
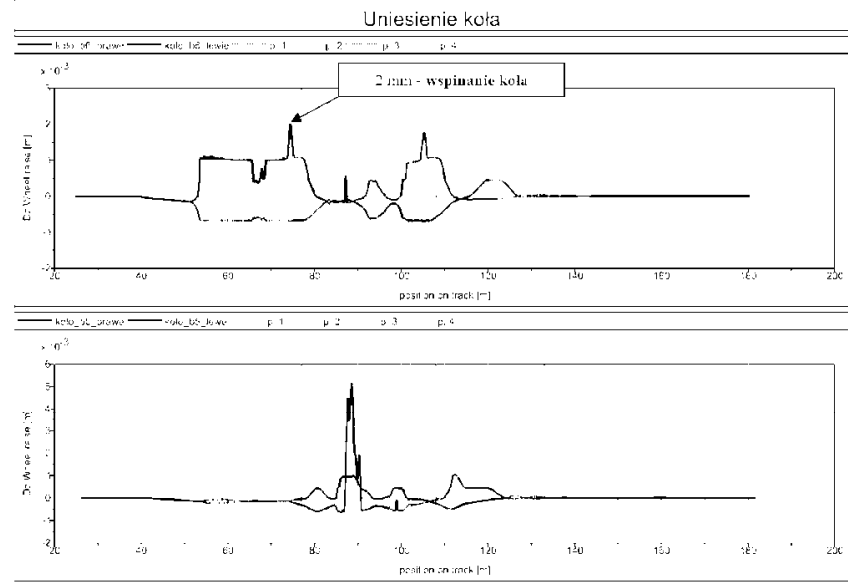

Rys. 5.3 - Pionowe unoszeni koła względem główki szyny siła ściskająca $264(240+10 \%) \mathrm{kN}$

Tabela 5.2 - Maksymalne uzyskane wartości poprzecznej siły lożyskowej na zestawie kołowym - siła ściskająca 264

\begin{tabular}{|c|c|c|c|c|}
\hline L.p. & $\begin{array}{c}\text { Zestaw } \\
\text { kołowy }\end{array}$ & $\begin{array}{c}\mathbf{Q}_{\mathbf{0}} \\
{[\mathbf{k N}]}\end{array}$ & $\begin{array}{c}\mathbf{H}_{\text {lim }} \\
{[\mathbf{k N}]}\end{array}$ & $\begin{array}{c}\mathbf{H} \\
{[\mathbf{k N}]}\end{array}$ \\
\hline 1 & $\mathrm{~b} 6$ & 20,0 & \pm 49 & $-12,7$ \\
\hline 2 & $\mathrm{~b} 5$ & 20,0 & \pm 49 & 25,0 \\
\hline 3 & $\mathrm{~b} 4$ & 16,6 & \pm 45 & 11,7 \\
\hline 4 & $\mathrm{~b} 3$ & 16,6 & \pm 45 & 13,7 \\
\hline 5 & $\mathrm{~b} 2$ & 19,1 & \pm 48 & $-25,0$ \\
\hline 6 & $\mathrm{~b} 1$ & 19,1 & \pm 48 & $\mathbf{- 4 2 , 0}$ \\
\hline 7 & $\mathrm{c} 1$ & 19,1 & \pm 48 & 19,1 \\
\hline 8 & $\mathrm{c} 2$ & 19,1 & \pm 48 & 18,9 \\
\hline 9 & $\mathrm{c} 3$ & 16,6 & \pm 45 & 11,1 \\
\hline 10 & $\mathrm{c} 4$ & 16,6 & \pm 45 & 13,0 \\
\hline 11 & $\mathrm{c} 5$ & 20,0 & \pm 49 & 11,5 \\
\hline 12 & $\mathrm{c} 6$ & 20,0 & \pm 49 & $-33,4$ \\
\hline
\end{tabular}

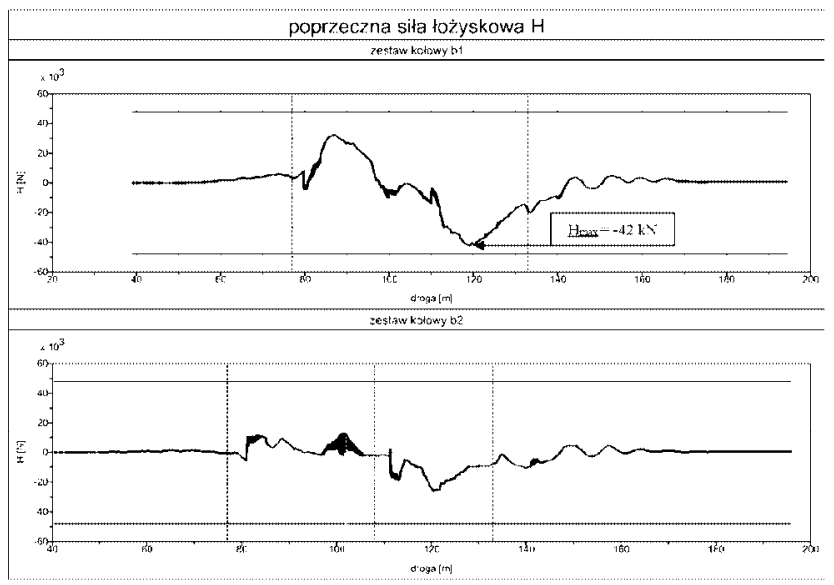

Rys. 5.4 - Maksymalna poprzeczna siła łożyskowa (H) na zestawie kołowym - siła ściskająca $264(240+10 \%) \mathrm{kN}$
Tabela 5.3 - Maksymalne uzyskane wartości przemieszczenia poprzecznego pomiędzy zderzakami - sila ściskająca 264 (240 $+10 \%) \mathrm{kN}$

\begin{tabular}{|c|c|}
\hline Zderzaki & $\begin{array}{c}\text { Przemieszczenie poprzeczne zderzaków } \\
\mathbf{d}_{\mathbf{v p}}[\mathbf{m m}]\end{array}$ \\
\hline przednie & 60,0 \\
\hline tylne & 250,0 \\
\hline
\end{tabular}

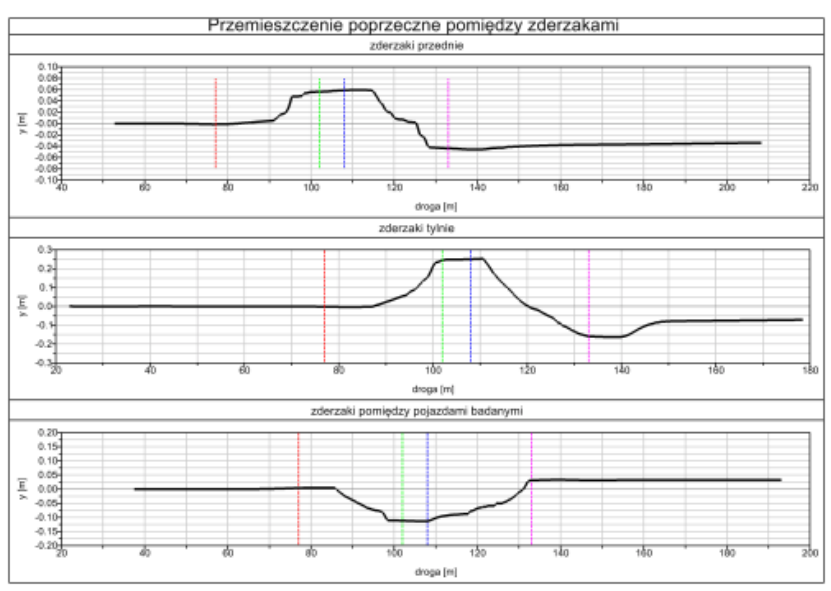

Rys. 5.5 - Przemieszczenie poprzeczne pomiędzy zderzakami zmodyfikowanego modelu pojazdu - siła ściskająca $264(240+$ $10 \%) \mathrm{kN}$

W tabeli 5.4 i 5.5 przedstawiono wybrane wyniki uzyskane podczas przejazdu konfiguracji uzupełniających pociaggu badawczego z siłą ściskającą wynoszącą $264(240+10 \%) \mathrm{kN}$

Wyniki przedstawione $\mathrm{w}$ tym rozdziale dla alternatywnej konstrukcji elementu łączącego wyszczególnionego na rysunku 5.1 są satysfakcjonujące. Tak zmodyfikowany pojazd przenosi wzdłużną siłę ściskającą na poziomie $264(240+10 \%) \mathrm{kN}$, co zapewnia spełnienie kryteriów określonych $\mathrm{w}$ karcie UIC 530-2.

\section{PODSUMOWANIE I WNIOSKI}

Przedstawione w artykule scenariusze badań opracowano na podstawie karty UIC 530-2 dla wagonów towarowych ze względu na bezpieczeństwo jazdy. Omówiono odpowiednie symulacje komputerowe badanego zestawu pojazdów do transportu kombinowanego (kolejowo-drogowego) po torze doświadczalnym w kształcie litery $\mathrm{S}$ z prędkością wynosząca $8 \mathrm{~km} / \mathrm{h}$. Przez zestaw rozumie się tutaj dwa pojazdy kolejowo-drogowe, w innym przypadku nie jest możliwe sprzęgnięcie badanych pojazdów z pojazdami wyposażonymi $\mathrm{w}$ standardowe urządzenia cięgłowo-zderzne, wynika to z specyficznej budowy badanych pojazdów (niestandardowe zderzaki i sprzęg $\mathrm{z}$ jednej strony pojazdu). W skład trzech przewidzianych w karcie [1] wariantów pociagu badawczego wchodzi jedna kombinacja standardowa i dwie uzupełniające. Pierwszy z omawianych składów 
Tabela 5.4 - Wyniki uzyskane podczas przejazdu konfiguracji uzupelniającej pociągu badawczego z długimi wagonami dwuosiowymi - sila ściskającą wynoszącą $264(240+10 \%)$ kN

\begin{tabular}{|c|c|c|c|c|c|c|c|}
\hline \multirow[b]{2}{*}{ L.p. } & \multirow{2}{*}{$\begin{array}{l}\text { Zestaw } \\
\text { kołowy }\end{array}$} & \multicolumn{3}{|c|}{ Wspinanie $d_{z}[\mathrm{~mm}]$} & \multicolumn{3}{|c|}{ Unoszenie $d_{z}[\mathrm{~mm}]$} \\
\hline & & $\mathbf{d z}_{\mathrm{lim}}$ & Koło lewe & $\begin{array}{l}\text { Kolo pra- } \\
\text { we }\end{array}$ & $\mathbf{d z} z_{\lim }$ & $\begin{array}{l}\text { Kolo } \\
\text { lewe }\end{array}$ & $\begin{array}{c}\text { Kolo } \\
\text { prawe }\end{array}$ \\
\hline 1 & $\mathrm{~b} 6$ & \multirow{12}{*}{5,0} & 0,9 & 1,0 & \multirow{12}{*}{50,0} & - & 2 \\
\hline 2 & b5 & & 0,9 & 1,0 & & 2 & 4 \\
\hline 3 & b4 & & 1,0 & 1,1 & & - & - \\
\hline 4 & b3 & & 0,4 & 0,3 & & - & - \\
\hline 5 & $\mathrm{~b} 2$ & & 1,1 & 1,1 & & - & - \\
\hline 6 & b1 & & 1,1 & 1,0 & & - & - \\
\hline 7 & $\mathrm{c} 1$ & & 1,1 & 1,1 & & - & - \\
\hline 8 & $\mathrm{c} 2$ & & 0,6 & 0,8 & & - & - \\
\hline 9 & c3 & & 1,1 & 1,0 & & - & - \\
\hline 10 & $\mathrm{c} 4$ & & 0,4 & 0,3 & & - & - \\
\hline 11 & $\mathrm{c} 5$ & & 1,1 & 1,1 & & - & - \\
\hline 12 & c6 & & 1,1 & 0,8 & & - & - \\
\hline
\end{tabular}

Tabela 5.5 - Wyniki uzyskane podczas przejazdu konfiguracji uzupelniającej pociągu badawczego z platformami towarowymi - sila ściskającą wynoszącą $264(240+10 \%) \mathrm{kN}$

\begin{tabular}{|c|c|c|c|c|c|c|c|}
\hline \multirow[b]{2}{*}{ L.p. } & \multirow{2}{*}{$\begin{array}{l}\text { Zestaw } \\
\text { kołowy }\end{array}$} & \multicolumn{3}{|c|}{ Wspinanie $d_{z}[\mathrm{~mm}]$} & \multicolumn{3}{|c|}{ Unoszenie $d_{z}[\mathrm{~mm}]$} \\
\hline & & $\mathbf{d z}_{\mathrm{lim}}$ & Koło lewe & $\begin{array}{c}\text { Kolo pra- } \\
\text { we } \\
\end{array}$ & $\mathbf{d z} \mathbf{z}_{\lim }$ & $\begin{array}{l}\text { Koło } \\
\text { lewe }\end{array}$ & $\begin{array}{c}\text { Kolo } \\
\text { prawe }\end{array}$ \\
\hline 1 & $\mathrm{~b} 6$ & \multirow{12}{*}{5,0} & 0,7 & 1,0 & \multirow{12}{*}{50,0} & 4,0 & 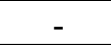 \\
\hline 2 & b5 & & 1,0 & 1,0 & & 5,7 & 2,5 \\
\hline 3 & b4 & & 1,1 & 1,0 & & - & - \\
\hline 4 & b3 & & 0,4 & 0,3 & & - & - \\
\hline 5 & b2 & & 1,1 & 1,1 & & - & - \\
\hline 6 & $\mathrm{~b} 1$ & & 1,0 & 1,1 & & - & - \\
\hline 7 & $\mathrm{c} 1$ & & 1,1 & 1,1 & & - & - \\
\hline 8 & $\mathrm{c} 2$ & & 0,7 & 0,8 & & - & - \\
\hline 9 & c3 & & 1,0 & 1,0 & & - & - \\
\hline 10 & c4 & & 0,4 & 0,5 & & - & - \\
\hline 11 & $\mathrm{c} 5$ & & 1,1 & 1,1 & & - & - \\
\hline 12 & c6 & & 1,0 & 1,0 & & - & - \\
\hline
\end{tabular}

pociagu badawczego zestawiony w konfiguracji standardowej zawiera poza badanymi pojazdami kolejowo-drogowymi dwa wagony, z przodu wagon typu FCS a z tyłu wagon typu RS. Kolejne składy zestawione $\mathrm{w}$ konfiguracjach uzupełniających, pierwszy wariant pociagu zawiera $\mathrm{z}$ przodu i tyłu wagon dwuosiowy o długości pomiędzy zderzakami $16 \mathrm{~m}$ i bazie wagonu $11 \mathrm{~m}$, drugi wariant pociagu badawczego $\mathrm{z}$ tyłu i przodu składa się z wagonów o takich samych parametrach geometrycznych, co badane pojazdy tzn. ta sama całkowita długość wagonu oraz taka sama baza wagonu. Podczas przeprowadzania symulacji pojazd do transportu kombinowanego był wyposażony w próżne naczepy drogowe, badania zostały wykonane przy współczynniku tarcia na zderzakach $\mu=$ 0,1 .

Podczas badań przeanalizowano wpływ wzdłużnej siły ściskającej powstającej podczas przejazdu przez tor badawczy w kształcie litery $\mathrm{S}$ na zachowanie się całego składu pociagu w trzech konfi- guracjach. W celu zachowania odpowiedniego poziomu bezpieczeństwa zwiększono wartość wymaganej wzdłużnej siły ściskającej o 10\% z 240 kN na 264 $\mathrm{kN}$ zgodnie z kartą [1].

Dla przejazdu w kombinacji standardowej maksymalna wartość wzdłużnej siły ściskającej zapewniającej bezpieczny przejazd przez tor badawczy w kształcie litery S wynosi $198 \mathrm{kN}$ i jest niższa od wymaganej dla wagonów towarowych wózkowej minimalnej wzdłużnej siły ściskającej, która wynosi $264(240+10 \%) \mathrm{kN}$. Obie konfiguracje uzupełniające okazały się mniej wrażliwe na wzdłużną siłę ściskająca, składy pociagów w tych konfiguracjach są w stanie w sposób bezpieczny przejechać przez tor badawczy w kształcie litery S przy wzdłużnej sile ściskającej wymaganej dla wagonów towarowych wyposażonych w wózki, czyli $240 \mathrm{kN}$ (przejazd został wykonany przy sile wyższej o $10 \%$ czyli $264 \mathrm{kN}$ ). Dla konfiguracji standardowej przy sile wzdłużnej 
przekraczającej 198 kN występuje nadmierne wspinanie się kół prowadzących pierwszego wózka pierwszego wagonu. Jedną z przyczyn takiego zachowania jest specyficzna budowa pojazdu powodująca stosunkowo duże odciążenie wózka znajdującego się pod przodem naczepy podczas przenoszenia przez wagon dużych wartości wzdłużnej siły ściskającej.

W przypadku zastosowania alternatywnej konstrukcji elementu łączącego platformę pod koła naczepy z ramą pod siodło naczepy oraz sztywniejszego wariantu naczepy wyniki przeprowadzonych badań symulacyjnych wskazuja, iż pojazd do transportu kombinowanego jest wstanie przenieść wzdłużną siłę ściskającą na poziomie $264(240+10 \%)$ $\mathrm{kN}$, co zapewnia spełnienie wytycznych zawartych $\mathrm{w}$ karcie UIC 530-2.

Podsumowując można stwierdzić, iż badana podstawowa konstrukcja pojazdu do transportu kombinowanego jest $\mathrm{w}$ stanie bezpiecznie przenieść wzdłużną siłę ściskającą do poziomu $198 \mathrm{kN}$ a więc nie spełnia wytycznych zawarte w karcie UIC 530-2 natomiast konstrukcja alternatywna opisana $\mathrm{w}$ rozdziale 5 przenosi siłę $264(240+10 \%) \mathrm{kN}$, więc spełnia wymagania zawarte $\mathrm{w}$ karcie UIC 530-2 dotyczącymi bezpieczeństwa przed wykolejenie pod wpływem siły wzdłużnej na łukach odwrotnych.

\section{Bibliografia}

[1] Kodeks UIC 530-2: Wagony towarowe Bezpieczeństwo jazdy, Międzynarodowy Zwiqzek Kolei UIC, 2011

[2] PN-EN 14363: Kolejnictwo. Badania własności dynamicznych dla dopuszczenia (homologacji) pojazdów szynowych. Badania własności biegowych $i$ próby stacjonarne. PKN, Warszawa 2007

[3] Medwid M.: Polski system transportu kolejowodrogowego (bimodalnego) typu TABOR, Wydawnictwo IPS “TABOR”, Poznań 2006

[4] Madej J., Medwid M.: Modułowy system transportu naczep siodłowych na wózkach kolejowych w ruchu kombinowanym kolejowo-drogowym, Pojazdy Szynowe, IPS “TABOR”, Poznań 02/2013

[5] Tomaszewski F., Medwid M., Nowaczyk T., Czerwiński J., ,Cechy charakterystyczne „,modułowego systemu transportu naczep drogowych" $w$ odniesieniu do znanych systemów transportowych $w$ ruchu intermodalnym kolejowo-drogowym", Materiaty konferencyjne: XXI Międzynarodowa Konferencja Naukowa Pojazdy Szynowe 2014, Wrocław, Wojanów 2014

[6] Madej J., Medwid M., Cichy R., Nowaczyk T., „Wybrane aspekty procesu tworzenia modelu modułowego systemu transportu naczep drogowych $w$ ruchu kombinowanym", Materiaty konferencyjne: XXI Międzynarodowa Konferencja Naukowa Pojazdy Szynowe 2014, Wrocław, Wojanów 2014

[7] Madej J., Medwid M., Stawecki W., „,Konstrukcja newralgicznych węzłów krańcowego wózka $w$ module kolejowego uformowania naczep drogowych", Materiaty konferencyjne: XXI Międzynarodowa Konferencja Naukowa Pojazdy Szynowe 2014, Wrocław, Wojanów 2014

[8] Medwid M., Lukaszewski K., Bryk K., „,Symulacyjne komputerowe badania dynamiczne modułowego pojazdu do transportu kombinowanego, kolejowodrogowego", Materiaty konferencyjne: XXI Międzynarodowa Konferencja Naukowa Pojazdy Szynowe 2014, Wrocław, Wojanów 2014 